\title{
Bottom-up effects of host plant nutritional quality on Plutella xylostella (Lepidoptera: Plutellidae) and top-down effects of herbivore attack on plant compensatory ability
}

\author{
RANA M. SARFRAZ ${ }^{1 *}$, Lloyd M. DOSDALL ${ }^{2}$ and ANDREw B. KEDDIE ${ }^{1}$ \\ ${ }^{1}$ Department of Biological Sciences, University of Alberta, Edmonton, Alberta, Canada T6G 2E9 \\ ${ }^{2}$ Department of Agricultural, Food and Nutritional Science, University of Alberta, Edmonton, Alberta, Canada T6G 2P5
}

Key words. Lepidoptera, Plutellidae, Plutella xylostella, diamondback moth, Brassicaceae, insect-plant interactions, plant vigour, plant stress, soil fertilizer treatments

\begin{abstract}
The plant stress and plant vigour hypotheses are competing paradigms pertaining to the preference and performance of herbivorous insects on their host plants. Tests of these hypotheses ideally require detailed information on aspects of soil nutrition, foliar nutrient levels and parameters of herbivore fitness, but such studies are uncommon. These hypotheses were tested using the diamondback moth, Plutella xylostella (L.) (Lepidoptera: Plutellidae), reared on its host plant, Brassica napus (L.), grown in an experimental system of five nutrient regimes. Different levels of fertilizer treatments significantly affected the nutrient content of $B$. napus foliage and this in turn affected the preference and performance of $P$. xylostella. Ovipositing females discriminated among host plants grown in soils subjected to different fertilizer treatments and selected plants on which pre-imaginal survival was highest, development fastest and longevity of the next generation of adults the longest, even when food was scarce. Plants subjected to herbivory by $P$. xylostella responded by producing elevated levels of some nutrients (e.g., sulphur), but other nutrient levels declined in infested leaves (e.g., nitrogen). Regardless of the rate of fertilizer application, plants compensated for herbivory by increasing root mass compared to un-infested control plants; plants grown in soils receiving the optimum quantity of fertilizer developed the most robust root systems when infested. The plant stress and the plant vigour hypotheses are likely to be at the opposite ends of a continuum of responses between insects and their host plants. Our investigations indicate a complex set of interactions involving both bottom-up and top-down effects, which interact to affect host plant quality, oviposition site selection by female herbivores and the fitness of their offspring.
\end{abstract}

\section{INTRODUCTION}

Understanding ecological interactions among insect herbivores and their host plants has long been a goal of ecologists. A substantial body of literature implicates host plant quality as a primary player influencing herbivorehost plant interactions (Thompson, 1988a; Louda \& Collinge, 1992). Here, the basic premise is that insects will prefer to oviposit and feed on plants that confer the greatest fitness to themselves and their offspring (Thompson, 1988b; Craig et al., 1989; Denno et al., 1990; Fox \& Lalonde, 1993; Barker \& Maczka, 1996; Craig \& Ohgushi, 2002).

The preference/performance hypothesis is based on the premise that plants differ in their quality as hosts for herbivorous insects. Numerous studies show that differences in plant quality reflect the availability of soil nutrients. Total numbers of leaves, main stem diameters and root masses are considered important plant morphological indices (Gartner, 1994; Tekeli \& Ates, 2003). Variation in soil nutrients affects the production of plant defensive chemicals (Inbar et al., 2001; Marazzi et al., 2004; Ramona et al., 2005), plant morphology and quality (Chau \& Heinz, 2006) and in turn can influence the pref- erence and performance of insect herbivores. Hypotheses of "plant stress" and "plant vigour" predict the responses of herbivores to soil nutrients, as mediated by host plant quality.

The plant stress hypothesis of White (1984) predicts that stressed plants serve as better hosts for insect herbivores. According to this hypothesis, plants under stress are more suitable for insect herbivores due to increased nutritional quality arising from reduced protein synthesis and increased free amino acids in plant tissues (White, 1969, 1984; Mattson \& Haack, 1987) and reduced synthesis of defensive chemicals (Rhoades, 1979). The effect of plant stress often varies with the insect feeding guild, the host plant species, and the nature and level of stress (Heinrichs, 1988; Larsson, 1989; Waring \& Cobb, 1992). Certain insects (e.g. phloem feeders) prefer stressed plants whereas others (e.g. leaf chewers, leafminers) are negatively affected when feeding on stressed plants (Larsson, 1989; Koricheva et al., 1998; Inbar et al., 2001). For instance, whiteflies, Bemisia tabaci (Gennadius) and $B$. argentifolii Bellows \& Perring (Homoptera: Aleyrodidae), prefer stressed cotton plants (Flint et al., 1996; Skinner, 1996) while performance of grass miners, Chro-

\footnotetext{
* Corresponding address: Department of Zoology and Biodiversity, University of British Columbia, 2370-6270 University Blvd.,
} Vancouver, British Columbia, Canada V6T 1Z4; e-mail: rsarfraz@zoology.ubc.ca 
matomyia milii (Kaltenbach) (Diptera: Agromyzidae), significantly declines on stressed host plants (Scheirs \& Bruyn, 2005).

In contrast, the plant vigour hypothesis of Price (1991) proposes that herbivorous insects will prefer and perform better on fast-growing, vigorous plants or plant modules compared with slow-growing, less vigorous plants or plant modules. This hypothesis applies particularly to those insects for which there is a close association between the selection of oviposition sites by adults and larval feeding guild, and insects whose larval development is closely linked with host plant growth processes. For instance, galling and mining insects that have the most intimate relationships with their host plants seem to accord best with the predictions of this hypothesis (Price, 1991). However, the underlying mechanisms of the plant vigour hypothesis are unknown.

There is empirical support for both hypotheses. Some studies have shown that insects perform better on stressed plants (White, 1969, 1984; Mattson, 1980; Jones \& Coleman, 1988), but others indicate that vigorous plants frequently support higher densities of insect herbivores than their stressed counterparts (Price, 1991; Meyer \& Root, 1996; Inbar et al., 2001; Heisswolf et al., 2005). There is also evidence that some insect herbivores do not discriminate between stressed and vigorous host plants. For example, Diplolepis ignota Osten Sacken, D. nodulosa Beutenmüller and D. rosaefolii Cockerell (Hymenoptera: Cynipidae) respond similarly to vigorous and stressed rose plants (Williams \& Cronin, 2004). Host plant nutritional quality can therefore ameliorate, exacerbate, or have no effect at all on the host preference and performance of insect herbivores.

In the current study, we examined the effect of unfertilized versus four different fertilization treatments (two intermediate fertilizer treatments and two high fertilizer treatments) on various growth parameters of Brassica napus L. (Brassicaceae). These plants were used as hosts for the oligophagous herbivore Plutella xylostella (L.) (Lepidoptera: Plutellidae), for which several fitness correlates were measured (Fig. 1). Data were initially used to test for a relationship between plant preference and insect performance in order to better understand the ecological interactions and mechanisms involved in host plant selection and utilization by insect herbivores. Data were used subsequently to test predictions of the plant stress hypothesis versus the plant vigour hypothesis.

\section{MATERIAL AND METHODS}

\section{Insects and plants}

The laboratory colony of $P$. xylostella was maintained in the greenhouse and growth chambers on potted $B$. napus plants at $22 \pm 0.5^{\circ} \mathrm{C}$ and a $16 \mathrm{~L}: 8 \mathrm{D}$ photoperiod. Moths collected from different commercial fields throughout Alberta, Canada were added to the culture every summer to maintain genetic diversity. Plutella xylostella normally oviposit from 11 to 188 eggs per female on the adaxial surface of leaves (Harcourt, 1957; Talekar $\&$ Shelton, 1993). Neonates are usually leafminers that feed on the spongy mesophyll tissue, while instars 2 to 4 are leaf mass consumers that normally feed on the abaxial leaf surfaces; pupa- tion takes place on host plants or any other suitable substrate (Harcourt, 1957).

Brassica napus plants were grown individually in 15.2-cmdiameter pots using Metromix-220 (W.R. Grace \& Co., Ajax, Ontario, Canada) as a potting medium. Experimental plants were grown in one of four fertilizer treatments, viz. 0.5, 1.0, 3.0, $5.0 \mathrm{~g} \mathrm{pot}^{-1}$ of $20: 20: 20$ (nitrogen : phosphorus : potassium) (Plant Products Co. Ltd., Brampton, Ontario, Canada), while control plants were grown in soil without any added fertilizer. Fertilizer treatments were applied in two split applications to avoid any phytotoxic effects of higher concentrations: the first application of fertilizer was made two weeks after of seed germination and the second when plants were three weeks old. Each fertilizer application consisted of applying the concentrate dissolved in $100 \mathrm{ml}$ tap water while control plants received only $100 \mathrm{ml}$ water. Four-week-old plants were used in all the experiments.

\section{Plutella xylostella oviposition: Free-choice experiments}

Intact plant study

Ovipositional preference experiments were conducted with $P$. xylostella in a multiple choice manner in ten screened cages $(120 \times 120 \times 120 \mathrm{~cm})$ under greenhouse conditions using a randomized complete block design and each cage was considered a block. The entire experiment was repeated; i.e., a total of 20 cages were used. One plant from each fertilizer treatment and one from the water-only control were placed randomly into each cage (i.e., five plants per cage). A total of 20 adults (four moths per plant) were released in each cage in which there was also a $10 \%$ honey solution as a source of food for the adults. Moths were always $\leq 1 \mathrm{~d}$ old and were released in $1: 1(\mathrm{~m}: \mathrm{f}$ ) sex ratio from a container placed in the centre of the cage. Eggs on each plant were counted $3 \mathrm{~d}$ after releasing the moths.

\section{Leaf disc study}

A study with standardized leaf discs was conducted because leaf areas and/or leaf numbers might have influenced $P$. xylostella oviposition in the above intact plant study. In this experiment, therefore, leaf discs of equal area (diameter $=4.0$ $\mathrm{cm})$ were taken from plants in each fertilizer treatment and control plants and were placed on moist filter paper in $15-\mathrm{cm}-$ diameter Petri dishes; a total of 10 dishes were used and each one was considered a block. Leaf discs were placed equidistant from the centre of the Petri dish. A one-day-old mated female was released in the centre of each dish, and the numbers of eggs deposited on each leaf disc were recorded after $24 \mathrm{~h}$. This experiment was conducted in controlled environmental conditions in a growth chamber $\left(22 \pm 0.5^{\circ} \mathrm{C}\right.$ and $16 \mathrm{~L}: 8 \mathrm{D}$ photoperiod).

\section{Effects of different fertilizer treatments on insect life history traits}

Intact plant study: Survival of $P$. xylostella

Over 100 newly emerged $P$. xylostella were allowed to oviposit on tinfoil sheets treated with an extract of $B$. napus leaves (Shelton et al., 1991). After $24 \mathrm{~h}$, the tinfoil sheets, now with eggs on them, were cut into pieces with about 15 to 20 eggs on each piece and then incubated in individual plastic cups. Preimaginal survival was assessed in screened cages $(40 \times 40 \times 80$ $\mathrm{cm}$ ), arranged on a greenhouse bench in a completely randomized design with each cage considered one replicate. Each cage contained a single plant, grown in soil subjected to one of the four fertilizer treatments or without added fertilizer; the entire experiment used 10 plants per treatment and 50 cages. Five plants from each treatment were infested with first-instar larvae while the remainder served as un-infested controls. The first- 


\section{Fertilizer Treatments $\left(\mathrm{g} \mathrm{pot}^{-1}\right)$ \\ Brassica napus Parameters \\ Plutella xylostella Parameters}

\author{
$0.0:$ unfertilized \\ 0.5 : intermediate \\ 1.0 : intermediate \\ 3.0: high \\ 5.0: high
}

\author{
1. Un-infested Plants \\ - tissue nutrients (nitrogen, \\ phosphorus, potassium, \\ sulphur, calcium, magnesium, \\ and sodium) \\ - stem diameter \\ - leaf number \\ - root biomass
}

2. Infested Plants
tissue nutrients (nitrogen,
phosphorus, potassium,
sulphur, calcium, magnesium,
and sodium)
- $\quad$ stem diameter
- leaf number
- $\quad$ root biomass

\author{
1. Intact Plant Study (Greenhouse) \\ - oviposition (choice) \\ - $\quad$ survival (neonate to pupa) \\ - $\quad$ survival (pupa to adult) \\ 2. Leaf Tissue Study (Growth Chamber) \\ a. Females \\ - oviposition (choice) \\ b. Females and Males \\ - development time (larva to pre-pupa) \\ - development time (pre-pupa to pupa) \\ - development time (pupa to adult) \\ - development time (larva to adult) \\ - foliage consumption \\ - pupal weight \\ - silk weight \\ - adult longevity (without food) \\ - $\quad$ adult body weight \\ - forewing area
}

Fig. 1. Overview of the effects of the different fertilizer treatments on Brassica napus and its herbivore Plutella xylostella, and top-down effects of herbivore attack on plant compensatory ability. Readers should focus particularly on the underlined parameters.

instar larvae were gently shaken from the incubation cups and when they dropped on silk threads 10 were transferred at random to each plant by suspending them from the silk thread entangled in the hairs of a fine brush. The pre-imaginal development of the larvae on each plant and the number of surviving individuals were recorded daily. Pupae were weighed and kept individually in transparent plastic cups until adult emergence.

Leaf tissue study: Pre-imaginal and imaginal parameters

This experiment was conducted in controlled environmental conditions in a growth chamber $\left(22 \pm 0.5^{\circ} \mathrm{C}\right.$ with $\left.16 \mathrm{~L}: 8 \mathrm{D}\right)$. Excised leaves were placed on moist filter paper $(9-\mathrm{cm}$ diameter) in ventilated plastic containers. For each treatment, 100 larvae, which had moulted to the second instar within the preceding $24 \mathrm{~h}$, were introduced into individual plastic containers in a completely randomized design; a total of 500 larvae were used, with 100 replicates per treatment. Larvae were provided with fresh leaf tissue of their respective treatment plants every $24 \mathrm{~h}$ until pupation. Developmental times from secondinstar larva to pre-pupa and from pre-pupa to pupa were recorded. Pupae were weighed within $24 \mathrm{~h}$ of pupation, returned to their respective containers and the time from pupation to adult emergence recorded. After adult emergence, the silk cocoons were also weighed using a Sartorius Supermicro ${ }^{\circledR}$ Balance (Sartorius Inc., Edgewood, NY, USA). Adults were sexed and used to determine their longevity, when kept without food, body weight and area of the forewing.

To quantify the amount of food eaten by larvae, all leaves damaged by $P$. xylostella larvae were scanned daily into a digital format using a desktop scanner (Umax Powerlook 2100XL Flatbed Scanner, UMAX Technologies Inc., Dallas, TX, USA) and the final version (250 dpi) was saved as a TIFF file without LZW compression. Image $J$ (National Institutes of Health, Bethesda, MD, USA) was used to quantify the area of leaf consumed by the larvae.

The longevities of 20 females and 20 males ( $<1$ day old) kept without food, which had completed their development on plants subject to each of the fertilizer treatments, were determined.
Moths were placed in individual plastic containers at $22 \pm 0.5^{\circ} \mathrm{C}$ and a $16 \mathrm{~L}: 8 \mathrm{D}$ photoperiod and examined daily until they died. In a separate experiment, 20 females and 20 males ( $\leq 1$ day old) of $P$. xylostella, reared as above, were killed and their wet body masses determined using a Sartorius Supermicro ${ }^{\circledR}$ Balance (Sartorius Inc., Edgewood, NY, USA). Their forewings were carefully removed, glued onto paper, scanned using a desktop scanner (Umax Powerlook 2100XL Flatbed Scanner, UMAX Technologies Inc., Dallas, TX, USA) and the wing areas measured using Image J (Sarfraz et al., 2007).

\section{Plant parameters}

Stem diameter and number of leaves

To assess plant quality, stem diameter was measured using vernier calipers (Digital Calipers, Samona International) at two points at the end of the larval development experiment; one measurement was made at the root/shoot junction and the other $10 \mathrm{~cm}$ above the root/shoot junction. Total number of leaves per plant was also counted at the beginning of the experiment.

\section{Tissue nutrient analysis}

Five leaves from each replicate and from both infested and un-infested (control) plants were collected at the end of larval development experiment, air-dried at room temperature, ground and subjected to nutrient analysis. The combustion method (AOAC-990.03) was used to determine total nitrogen and sulphur (AOAC International, 2003a) while calcium, phosphorus, potassium, magnesium and sodium were assessed by using the inductively coupled plasma spectroscopic method (AOAC-985.01) in Norwest Labs, Lethbridge, Canada (AOAC International, 2003b).

Root masses: Plant response to herbivory

At the end of the life history traits experiment, plants were uprooted; their roots were carefully washed as described by Gartner (1994) and air-dried at room temperature. The roots were removed and weighed to determine the effects of different 
soil fertilizer treatments on root development when infested and not infested by $P$. xylostella larvae.

\section{Statistical analyses}

Plutella xylostella oviposition: Free-choice experiments

Transformations $[\ln (x+1)]$ were used to achieve normality and homoscedasticity before analyses (Steel et al., 1997), but untransformed means are used in figure. The GLM procedure (PROC GLM, SAS 9.1.2) for a randomized complete block design was performed with cage/Petri dish as a blocking factor. PROC GLM analyses data within the framework of general linear model, and can handle models relating one or several dependent variables (continuous) to one or several independent variables (continuous or classification). PROC GLM can be used for many different statistical analyses including the analysis of variance (ANOVA) (SAS Institute, 2004). Differences between treatments were determined in the ANOVA table, and means were compared at the $5 \%$ level of significance using Tukey's studentized range test (Littell et al., 2002; SAS Institute, 2004). Since the oviposition choice study was repeated, each repetition was considered as an independent experiment. A new variable was generated (Experiment 1 and Experiment 2) and PROC GLM was performed to determine its level of significance in the ANOVA table, but combined data across both experiments are presented (Fig. 2).

Insect life history traits and plant parameters

Transformations $\left[(\mathrm{x}+0.5)^{0.5}, \ln (\mathrm{x}+1)\right]$ were used throughout when necessary to achieve normality and homoscedasticity before analyses (Steel et al., 1997), but untransformed means are presented in figures and tables. The GLM procedure (PROC GLM, SAS 9.1.2) for a completely randomized design was performed to test the differences between treatments in the ANOVA table and means were compared at the 5\% level of significance using Tukey's studentized range test (Littell et al., 2002; SAS Institute, 2004). T-tests (PROC TTEST) were performed for pair-wise comparison of the development times, larval herbivory, pupal weights, silk weights, adult body weights, forewing areas and longevities (without food) of females and males when they were reared on host plants grown under the various fertilizer treatments. PROC TTEST was also performed for pair-wise comparisons of the various nutrient contents and root masses of infested and un-infested (control) plants for each treatment separately (SAS Institute, 2004).

\section{RESULTS}

\section{Plutella xylostella oviposition: Free-choice experiments} Intact plant study

Fertilizer treatment had a highly significant effect on the ovipositional preference of $P$. xylostella $\left(F_{4,36}=84.32\right.$, $P<0.001$ ) (Fig. 2). Mean numbers of $P$. xylostella eggs deposited on plants that received $1.0 \mathrm{~g}$ of fertilizer pot $^{-1}$ significantly exceeded those deposited on un-treated controls and plants that received $0.5,3.0$ and $5.0 \mathrm{~g}$ of fertilizer pot $^{-1}$ (Fig. 2). The mean number of eggs deposited on plants receiving $5.0 \mathrm{~g}$ of fertilizer pot $^{-1}$ were similar to those deposited on un-treated controls, but significantly lower than on plants receiving 0.5 and $3.0 \mathrm{~g}$ of fertilizer pot $^{-1}$ (Fig. 2).

\section{Leaf disc study}

Fertilizer treatment significantly affected the preference of $P$. xylostella for ovipositing on particular leaf discs $\left(F_{4,36}=38.02, P<0.001\right)$ (Fig. 2). Overall the oviposition

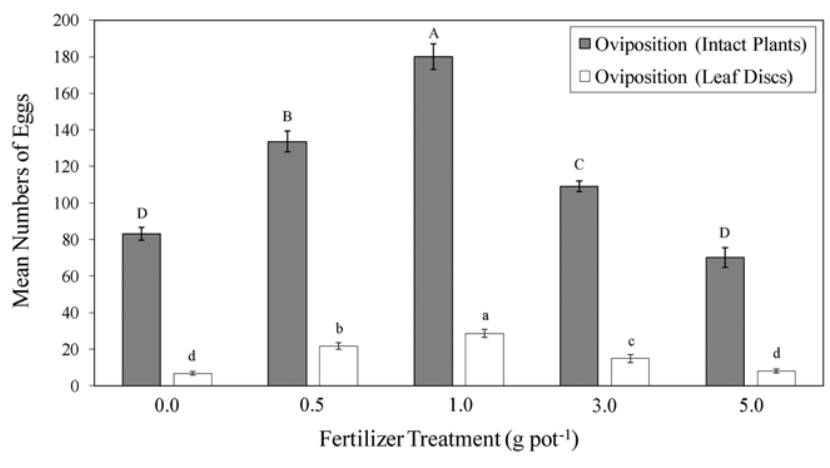

Fig. 2. Mean ( \pm S.E.) oviposition by Plutella xylostella females per plant or per leaf disc of Brassica napus in freechoice tests in a greenhouse (intact plant study) and growth chamber (leaf disc study). Brassica napus plants were grown in soils that received different fertilizer treatments. Means sharing the same letter (upper and lower case) do not differ significantly $(P=0.05)$ based on analysis of variance and Tukey's studentized range test.

preference was similar to that observed in the intact plant study with most eggs deposited on leaf discs taken from plants that received $1.0 \mathrm{~g}$ of fertilizer pot $^{-1}$ (Fig. 2).

\section{Effects of different fertilizer treatments on insect life history traits}

\section{Survival rate}

Plutella xylostella survival from neonate to pupa $\left(F_{4,36}\right.$ $=14.50, P<0.001)$ and pupa to adult $\left(F_{4,36}=9.59, P<\right.$ $0.001)$ varied significantly on plants grown in the different fertilizer treatments (Fig. 3). Highest percentage larval survival (neonate to pupa) occurred on plants treated with $1.0 \mathrm{~g}$ of fertilizer pot $^{-1}$ whereas larvae on plants treated with $5.0 \mathrm{~g} \mathrm{pot}^{-1}$ had the lowest percentage survival. Survival from neonate to pupa did not differ on plants that received $0.5,1.0$ or $3.0 \mathrm{~g}$ of fertilizer pot $^{-1}$. Lowest pupa to adult survival was recorded on plants treated with $5.0 \mathrm{~g} \mathrm{pot}^{-1}$ (Fig. 3).

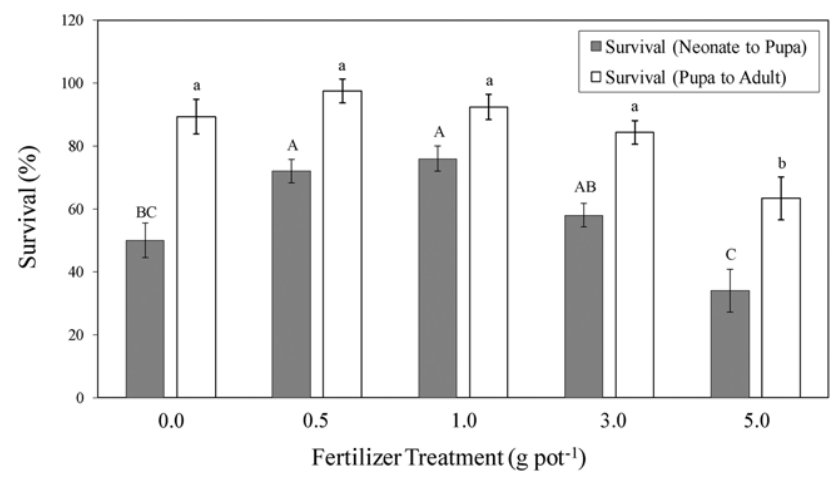

Fig. 3. Mean ( \pm S.E.) percent survival of Plutella xylostella from neonate to pupa and pupa to adult on intact Brassica napus plants grown in soils that received different fertilizer treatments. Means sharing the same letter (upper and lower case) do not differ significantly $(P=0.05)$ based on analysis of variance and Tukey's studentized range test. 
TABLE 1. Mean ( \pm S.E.) developmental time in days of the female and male larvae of Plutella xylostella reared on leaf tissue of Brassica napus plants grown in soil that received one of five different fertilizer treatments.

\begin{tabular}{|c|c|c|c|c|c|c|}
\hline \multirow{2}{*}{ Biological parameters } & & \multicolumn{5}{|c|}{ Fertilizer treatment $\left(\mathrm{g} \mathrm{pot}^{-1}\right)$} \\
\hline & & 0.0 & 0.5 & 1.0 & 3.0 & 5.0 \\
\hline \multirow{2}{*}{ Larva to pre-pupa } & Female & $7.6 \pm 0.2^{a}$ & $6.8 \pm 0.2^{b}$ & $6.4 \pm 0.2^{b}$ & $6.5 \pm 0.2^{b}$ & $7.6 \pm 0.3^{a}$ \\
\hline & Male & $7.4 \pm 0.2^{\mathrm{a}}$ & $6.9 \pm 0.2^{\mathrm{a}}$ & $5.9 \pm 0.1^{b}$ & $6.0 \pm 0.1^{\mathrm{b}}$ & $7.3 \pm 0.3^{\mathrm{a}}$ \\
\hline \multirow{2}{*}{ Pre-pupa to pupa } & Female & $1.1 \pm 0.1^{\mathrm{ab}}$ & $1.0 \pm 0.0 \mathrm{ab}$ & $0.9 \pm 0.1^{b}$ & $1.1 \pm 0.1^{\mathrm{ab}}$ & $1.3 \pm 0.1^{\mathrm{a}}$ \\
\hline & Male & $1.0 \pm 0.0^{\mathrm{a}}$ & $0.8 \pm 0.1^{\mathrm{a}}$ & $1.0 \pm 0.1^{\mathrm{a}}$ & $1.1 \pm 0.1^{\mathrm{a}}$ & $1.0 \pm 0.1^{\mathrm{a}}$ \\
\hline \multirow{2}{*}{ Pupa to adult } & Female & $4.5 \pm 0.2^{\mathrm{a}}$ & $4.2 \pm 0.1^{\mathrm{a}}$ & $3.1 \pm 0.2^{b}$ & $4.0 \pm 0.2^{\mathrm{a}}$ & $4.5 \pm 0.3^{\mathrm{a}}$ \\
\hline & Male & $5.1 \pm 0.2^{\mathrm{a}}$ & $4.1 \pm 0.2^{b}$ & $4.5 \pm 0.2^{\mathrm{ab}}$ & $4.5 \pm 0.2^{\mathrm{ab}}$ & $5.1 \pm 0.2^{\mathrm{a}}$ \\
\hline \multirow{2}{*}{ Larva to adult } & Female & $13.2 \pm 0.3^{\mathrm{a}}$ & $12.0 \pm 0.3^{b}$ & $10.4 \pm 0.3^{\mathrm{c}}$ & $11.6 \pm 0.3^{b}$ & $13.4 \pm 0.4^{\mathrm{a}}$ \\
\hline & Male & $13.5 \pm 0.3^{\mathrm{a}}$ & $11.8 \pm 0.4^{b}$ & $11.4 \pm 0.3^{\mathrm{b}}$ & $11.6 \pm 0.2^{b}$ & $13.4 \pm 0.4^{\mathrm{a}}$ \\
\hline
\end{tabular}

Means in a row followed by the same letter do not differ significantly $(P=0.05)$ based on analysis of variance and Tukey's studentized range test.

\section{Developmental time}

Fertilizer treatments strongly affected developmental time from neonate to pre-pupa, pupa to adult and neonate to adult of both females $\left(F_{4,76}=10.18, P<0.001 ; F_{4,76}=\right.$ 9.63, $P<0.001$ and $F_{4,76}=20.05, P<0.001$ respectively) and males $\left(F_{4,76}=15.35, P<0.001 ; F_{4,76}=4.95, P=0.001\right.$ and $F_{4,76}=10.95, P<0.001$ respectively) (Table 1). Prepupal development time was significantly affected in females $\left(F_{4,76}=3.70, P=0.008\right)$, but not males $\left(F_{4,76}=\right.$ $1.74, P=0.149)$ (Table 1). Both female and male larval development was fastest on plants treated with $1.0 \mathrm{~g}$ fertilizer pot $^{-1}$, and differed significantly from larvae reared on plants treated with 0.0 and $5.0 \mathrm{~g} \mathrm{pot}^{-1}$ (Table 1). Female pre-pupal development was fastest on plants that received $1.0 \mathrm{~g}$ fertilizer pot $^{-1}$ and slowest on plants that received $5.0 \mathrm{~g}$ fertilizer pot $^{-1}$. Male pupae developed fastest on plants that received $0.5 \mathrm{~g}$ fertilizer pot $^{-1}$ whereas female pupal development was fastest on plants that received $1.0 \mathrm{~g}$ fertilizer pot $^{-1}$. For both females and males, overall development from neonate to adult was fastest on plants treated with $1.0 \mathrm{~g}$ fertilizer pot ${ }^{-1}$ (Table 1).

\section{Foliage consumption}

Area of foliage consumed by female and male $P$. xylostella larvae varied significantly $\left(F_{4,76}=12.47, P<\right.$ 0.001 and $F_{4,76}=3.83, P=0.007$ respectively) (Table 2). Female larvae consumed similar area of leaf when reared on plants that received $0.0,0.5$ or $1.0 \mathrm{~g}$ of fertilizer whereas male larvae consumed a greater area of the foliage of un-fertilized plants than of those that received $1.0,3.0$ or $5.0 \mathrm{~g}$ of fertilizer pot ${ }^{-1}$ (Table 2).

\section{Pupal and silk weights}

Pupal and silk weights differed significantly for females ( $F_{4,76}=6.67, P<0.001$ and $F_{4,76}=4.23, P=0.004$ respectively) and males $\left(F_{4,76}=5.04, P=0.001\right.$ and $F_{4,76}=14.68$, $P<0.001$ respectively) when reared on host plants grown in soil that was treated with fertilizer. For both female and male specimens, the heaviest pupae and silk cocoons were produced by larvae reared on plants that received $1.0 \mathrm{~g}$ of fertilizer pot ${ }^{-1}$ (Table 2).

\section{Adult body weight, forewing area, and longevity}

Fertilizer treatments significantly affected adult body weight, forewing area and longevity of starved females $\left(F_{4,76}=4.55, P=0.002 ; F_{4,76}=5.58, P=0.001\right.$ and $F_{4,76}=$ 6.23, $P=0.002$ respectively $)$ and males $\left(F_{4,76}=9.98, P<\right.$ $0.001 ; F=11.06, P<0.001$ and $F_{4,76}=25.95, P<0.001$ respectively) (Table 3 ). Adult males and females were heaviest when they were reared as larvae on plants that received 3.0 or $1.0 \mathrm{~g}$ of fertilizer pot $^{-1}$, respectively. Moths reared on plants that received $1.0 \mathrm{~g}$ of fertilizer pot $^{-1}$ lived longer than those reared on plants that received $0.0,0.5,3.0$ or $5.0 \mathrm{~g}$ of fertilizer pot ${ }^{-1}$. The specimens with the largest forewings were reared on plants that received $1.0 \mathrm{~g}$ of fertilizer pot $^{-1}$ (Table 3 ).

TABle 2. Mean ( \pm S.E.) foliage consumption $\left(\mathrm{cm}^{2}\right)$, pupal weights $(\mathrm{mg})$ and silk weights $(\mathrm{mg})$ of female and male Plutella xylostella whose larvae were reared on leaf tissue of Brassica napus plants grown in soil that received one of five different soil fertilizer treatments.

\begin{tabular}{lcccccc}
\hline \multirow{2}{*}{ Biological parameters } & & \multicolumn{5}{c}{${\text { Fertilizer treatment }\left(\mathrm{g} \mathrm{pot}^{-1}\right)}$} \\
\cline { 3 - 7 } & & 0.0 & 0.5 & 1.0 & 3.0 & 5.0 \\
\hline \multirow{2}{*}{ Foliage consumed } & Female & $2.7 \pm 0.1^{\mathrm{a}}$ & $2.9 \pm 0.3^{\mathrm{a}}$ & $3.1 \pm 0.2^{\mathrm{a}}$ & $1.8 \pm 0.3^{\mathrm{b}}$ & $1.8 \pm 0.1^{\mathrm{b}}$ \\
& Male & $2.3 \pm 0.1^{\mathrm{a}}$ & $2.1 \pm 0.1^{\mathrm{ab}}$ & $1.8 \pm 0.2^{\mathrm{b}}$ & $1.7 \pm 0.0^{\mathrm{b}}$ & $1.7 \pm 0.1^{\mathrm{b}}$ \\
\multirow{2}{*}{ Pupal weight } & Female & $6.5 \pm 0.2^{\mathrm{bc}}$ & $6.9 \pm 0.3^{\mathrm{abc}}$ & $7.7 \pm 0.2^{\mathrm{a}}$ & $7.3 \pm 0.2^{\mathrm{ab}}$ & $6.4^{\mathrm{a}} \pm 0.2^{\mathrm{c}}$ \\
& Male & $5.9 \pm 0.2^{\mathrm{c}}$ & $6.5 \pm 0.2^{\mathrm{ab}}$ & $6.7 \pm 0.1^{\mathrm{a}}$ & $6.4 \pm 0.1^{\mathrm{abc}}$ & $6.0 \pm 0.2^{\mathrm{bc}}$ \\
\multirow{3}{*}{ Silk weight } & Female & $0.19 \pm 0.01^{\mathrm{ab}}$ & $0.20 \pm 0.01^{\mathrm{ab}}$ & $0.24 \pm 0.01^{\mathrm{a}}$ & $0.22 \pm 0.02^{\mathrm{a}}$ & $0.17 \pm 0.02^{\mathrm{b}}$ \\
& Male & $0.18 \pm 0.01^{\mathrm{c}}$ & $0.21 \pm 0.01^{\mathrm{bc}}$ & $0.26 \pm 0.01^{\mathrm{a}}$ & $0.23 \pm 0.01^{\mathrm{ab}}$ & $0.19 \pm 0.01^{\mathrm{c}}$ \\
\hline
\end{tabular}

Means in a row followed by the same letter do not differ significantly $(P=0.05)$ based on analysis of variance and Tukey's studentized range test. 
TABLE 3. Mean ( \pm S.E.) adult body weights (mg), longevity without food (days) and forewing areas $\left(\mathrm{mm}^{2}\right)$ of female and male Plutella xylostella whose larvae were reared on leaf tissue of Brassica napus plants grown in soil that received one of five different soil fertilizer treatments.

\begin{tabular}{|c|c|c|c|c|c|c|}
\hline \multirow{2}{*}{ Biological parameters } & & \multicolumn{5}{|c|}{ Fertilizer treatment $\left(\mathrm{g} \mathrm{pot}^{-1}\right)$} \\
\hline & & 0.0 & 0.5 & 1.0 & 3.0 & 5.0 \\
\hline \multirow{2}{*}{ Adult body weight } & Female & $2.6 \pm 0.1^{\mathrm{ab}}$ & $2.5 \pm 0.1^{b}$ & $3.0 \pm 0.1^{\mathrm{a}}$ & $2.5 \pm 0.1^{b}$ & $2.8 \pm 0.1^{\mathrm{ab}}$ \\
\hline & Male & $2.2 \pm 0.1^{\mathrm{c}}$ & $2.6 \pm 0.1^{\mathrm{bc}}$ & $2.9 \pm 0.1 \mathrm{ab}$ & $3.1 \pm 0.1^{\mathrm{a}}$ & $2.3 \pm 0.1^{\mathrm{c}}$ \\
\hline \multirow{2}{*}{ Longevity without food } & Female & $6.7 \pm 0.2^{b}$ & $6.7 \pm 0.2^{b}$ & $7.9 \pm 0.2^{\mathrm{a}}$ & $7.0 \pm 0.2^{b}$ & $7.1 \pm 0.3^{b}$ \\
\hline & Male & $5.6 \pm 0.1^{\mathrm{c}}$ & $6.2 \pm 0.3^{c}$ & $7.7 \pm 0.2^{\mathrm{a}}$ & $7.0 \pm 0.2^{b}$ & $6.1 \pm 0.2^{c}$ \\
\hline \multirow{2}{*}{ Forewing area } & Female & $16.7 \pm 0.3^{b}$ & $17.7 \pm 0.4^{\mathrm{ab}}$ & $19.6 \pm 0.6^{\mathrm{a}}$ & $18.4 \pm 0.4^{\mathrm{ab}}$ & $19.1 \pm 0.6^{\mathrm{a}}$ \\
\hline & Male & $15.8 \pm 0.8 \mathrm{bc}$ & $15.0 \pm 0.3^{c}$ & $18.5 \pm 0.4^{\mathrm{a}}$ & $17.4 \pm 0.2^{\mathrm{ab}}$ & $14.5 \pm 0.5^{\mathrm{c}}$ \\
\hline
\end{tabular}

Means in a row followed by the same letter do not differ significantly $(P=0.05)$ based on analysis of variance and Tukey's studentized range test.

Females versus males

Both females and males reared on B. napus plants grown in pots that received different amounts of fertilizer differed in their life history traits (Table 4). Female pupal development was significantly slower than that of males when reared on plants that received 1.0 or $3.0 \mathrm{~g}$ of fertilizer pot $^{-1}$. Overall development from neonate to adult was faster for females than males when reared on plants that received $1.0 \mathrm{~g}$ of fertilizer pot $^{-1}$, but development time did not differ for females and males in any other tested fertilizer treatment. Female larvae consumed more leaf tissue than male larvae of plants that received 0.5 or $1.0 \mathrm{~g}$ of fertilizer pot $^{-1}$. When starved, females lived longer than males if they were reared as larvae on plants that received 0.0 or $5.0 \mathrm{~g}$ of fertilizer pot $^{-1}$. In addition, females had larger forewings than males when reared on plants grown in soil that received either 0.5 or $5.0 \mathrm{~g}$ of fertilizer pot $^{-1}$ (Table 4).

\section{Plant parameters}

Stem diameter and numbers of leaves

Fertilizer treatments strongly affected plant basal stem diameter $\left(F_{4,36}=13.05, P<0.001\right)$ and stem diameter 10 $\mathrm{cm}$ above the soil-stem interface $\left(F_{4,36}=51.34, P<0.001\right)$ (Fig. 4). At the soil-stem interface, stem diameter was similar for plants grown in soil that received 0.5, 1.0, 3.0 or $5.0 \mathrm{~g}$ of fertilizer pot ${ }^{-1}$. Plants that grew in soils that received 3.0 or $5.0 \mathrm{~g}$ of fertilizer pot $^{-1}$ had the largest stem diameters at $10 \mathrm{~cm}$ above the soil-stem interface (Fig. 4).

Mean numbers of leaves per plant varied significantly across the different fertilizer treatments $\left(F_{4,36}=22.64, P<\right.$ $0.001)$. Plants that grew in soil that received 3.0 or $5.0 \mathrm{~g}$ of fertilizer pot $^{-1}$ had the most leaves followed by those that received 1.0 or $0.5 \mathrm{~g} \mathrm{pot}^{-1}$ whereas fewest leaves occurred on plants grown in soil that received no added fertilizer $(17.3 \pm 1.0,17.1 \pm 0.5,14.4 \pm 0.8,14.3 \pm 0.7$ and $9.2 \pm 0.4$, respectively).

Tissue nutrient analysis

Soil fertilizer treatments strongly affected the concentration of nutrients in the leaves of un-infested $B$. napus plants and those infested with $P$. xylostella larvae (Table 5). Leaf nitrogen content increased with increasing levels of fertilizer application both for infested and un-infested leaves, but mean nitrogen concentrations in infested leaves were consistently lower than those in their uninfested counterparts for each fertilizer application rate (Tables 5 and 6). The highest levels of phosphorus occurred in plants grown in soils that received $1.0 \mathrm{~g}$ of fertilizer pot $^{-1}$, and these differed significantly from the levels in the controls and other plants grown in soils that were treated with fertilizer. No significant differences were observed in phosphorus content of infested and uninfested plants grown in soils that received 0.5 or $1.0 \mathrm{~g}$ of

TABle 4. Pair-wise comparisons ( $t$-values) of some key life history parameters of female and male Plutella xylostella whose larvae were reared on Brassica napus grown in soils that received one of five soil fertilizer treatments.

\begin{tabular}{|c|c|c|c|c|c|}
\hline \multirow{2}{*}{ Biological parameters } & \multicolumn{5}{|c|}{ Fertilizer treatment $\left(\mathrm{g} \mathrm{pot}^{-1}\right)$} \\
\hline & 0.0 & 0.5 & 1.0 & 3.0 & 5.0 \\
\hline Development time (L-PP) & $0.84^{\mathrm{ns}}$ & $-0.39^{\mathrm{ns}}$ & $2.99 * *$ & $2.94 * *$ & $0.75^{\mathrm{ns}}$ \\
\hline Development time (PP-P) & $1.95^{\mathrm{ns}}$ & $3.56^{* *}$ & $-1.00^{\mathrm{ns}}$ & $0.47^{\mathrm{ns}}$ & $1.83^{\mathrm{ns}}$ \\
\hline Development time (P-A) & $-2.11^{*}$ & $0.43^{\mathrm{ns}}$ & $-4.92 * * *$ & $-1.60^{\mathrm{ns}}$ & $-1.88^{\mathrm{ns}}$ \\
\hline Development time (L-A) & $-0.62^{\mathrm{ns}}$ & $0.46^{\mathrm{ns}}$ & $-2.44 *$ & $0.13^{\mathrm{ns}}$ & $0.00^{\text {ns }}$ \\
\hline Herbivory (per larva) & $2.38^{*}$ & $4.73 * * *$ & $4.83 * * *$ & $0.43^{\mathrm{ns}}$ & $0.74^{\mathrm{ns}}$ \\
\hline Pupal weight & $2.16^{*}$ & $0.98^{\mathrm{ns}}$ & $3.71 * * *$ & $3.65 * * *$ & $1.39^{\mathrm{ns}}$ \\
\hline Silk weight & $1.03^{\mathrm{ns}}$ & $-0.53^{\mathrm{ns}}$ & $-3.05^{* *}$ & $-0.65^{\mathrm{ns}}$ & $-0.79^{\text {ns }}$ \\
\hline Adult body weight & $2.84 * *$ & $-0.83^{\mathrm{ns}}$ & $-0.45^{\mathrm{ns}}$ & $-3.20 * *$ & $1.71 \mathrm{~ns}$ \\
\hline Adult longevity & $5.20 * * *$ & $1.64^{\mathrm{ns}}$ & $0.83^{\mathrm{ns}}$ & $0.00^{\mathrm{ns}}$ & $2.95 * *$ \\
\hline Forewing area & $0.90^{\mathrm{ns}}$ & $5.60 * * *$ & $1.47^{\mathrm{ns}}$ & $2.54 *$ & $5.67 * * *$ \\
\hline
\end{tabular}

ns $=$ non-significant at $P>0.05 ; *=$ significant at $P \leq 0.05 ; * *=$ significant at $P \leq 0.01 ; * * *=$ significant at $P \leq 0.001 ; \mathrm{L}=$ larva, $\mathrm{PP}$ = pre-pupa, $\mathrm{P}=$ pupa, $\mathrm{A}=$ adult. 


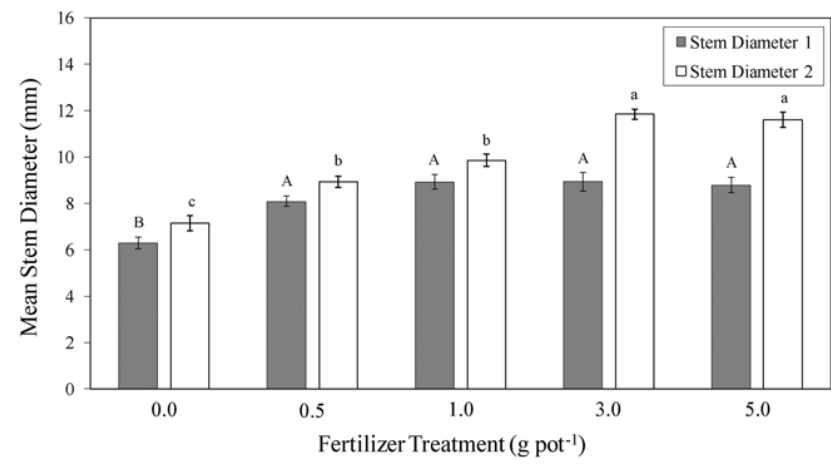

Fig. 4. Mean ( \pm S.E.) stem diameter 1 (soil-stem interface) and stem diameter $2(10 \mathrm{~cm}$ above the soil-stem interface) of Brassica napus plants grown in soils that received different fertilizer treatments. Means sharing the same letter (upper and lower case) do not differ significantly $(P=0.05)$ based on analysis of variance and Tukey's studentized range test.

fertilizer pot $^{-1}$. The potassium content of infested and uninfested plants grown in soils that received either, 0.5, 1.0 or $3.0 \mathrm{~g}$ of fertilizer pot $^{-1}$, differed significantly. The highest potassium content was recorded in infested plants grown in soils that received $1.0 \mathrm{~g}$ of fertilizer pot $^{-1}$ and the lowest in infested plants that received $5.0 \mathrm{~g} \mathrm{pot}^{-1}$ (Tables 5 and 6). In each fertilizer treatment, sulphur content was significantly higher in infested than un-infested plants. Leaf sulphur content declined with an increased application of fertilizer, with the highest levels recorded in infested plants grown in un-fertilized soil and the lowest in un-infested plants grown in soil that received $5.0 \mathrm{~g}$ of fertilizer pot $^{-1}$ (Tables 5 and 6).

\section{Root masses}

Effects of fertilizer treatments on root mass production (g dry weight) were highly significant for plants both infested and un-infested with $P$. xylostella larvae $\left(F_{4,16}=\right.$

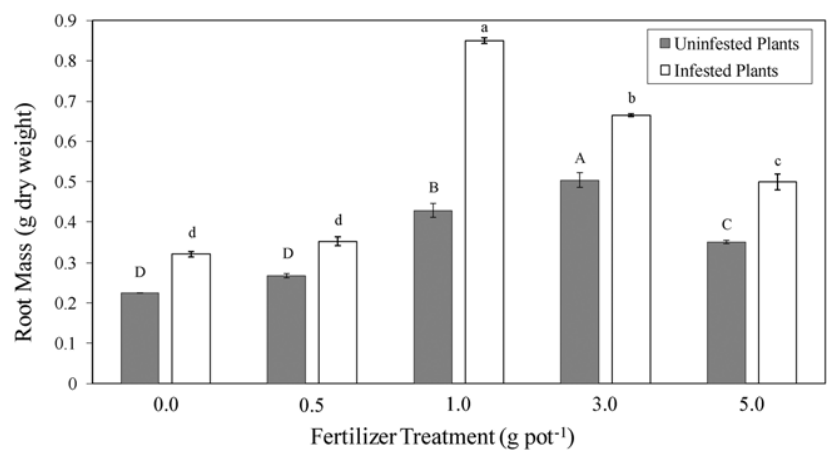

Fig. 5. Mean ( \pm S.E.) root mass development in Brassica napus plants grown in soils that received different fertilizer treatments when infested and not infested by Plutella xylostella larvae. Means sharing the same letter (upper and lower case) do not differ significantly $(P=0.05)$ based on analysis of variance and Tukey's studentized range test.

346.76, $P<0.001$ and $F_{4,16}=132.34, P<0.001$, respectively) (Fig. 5). For each fertilizer treatment viz. 0.0, 0.5, $1.0,3.0$ or $5.0 \mathrm{~g} \mathrm{pot}^{-1}$, the root masses of infested and uninfested plants differed significantly; the infested plants had larger root masses than the un-infested plants $(t=$ $14.13, P<0.001 ; t=7.35, P<0.001 ; t=22.45, P<$ $0.001 ; t=8.58, P<0.001$, and $t=7.33, P<0.001$, respectively). Of the un-infested plants, those grown in soils that received $3.0 \mathrm{~g}$ of fertilizer pot $^{-1}$ produced more robust root systems than the plants in all the other fertilizer treatments. When infested, plants grown in soils that received $1.0 \mathrm{~g}$ of fertilizer pot $^{-1}$ had significantly more robust root systems than the plants in all the other fertilizer treatments. Root masses of infested plants grown in soils that received $0.5 \mathrm{~g}$ of fertilizer pot $^{-1}$ did not differ significantly from those that received no added fertilizer (Fig. 5).

TABLE 5. Mean ( \pm S.E.) nutrients in leaf tissue of Brassica napus grown in soils that received different fertilizer treatments when un-infested ${ }^{\ddagger}$ and infested by Plutella xylostella larvae.

\begin{tabular}{|c|c|c|c|c|c|c|c|c|}
\hline \multirow{2}{*}{\multicolumn{2}{|c|}{ Leaf tissue nutrients (\%) }} & \multicolumn{5}{|c|}{ Fertilizer treatment $\left(\mathrm{g} \mathrm{pot}^{-1}\right)$} & \multirow[b]{2}{*}{$F_{4,16}$} & \multirow[b]{2}{*}{$P$} \\
\hline & & 0.0 & 0.5 & 1.0 & 3.0 & 5.0 & & \\
\hline \multirow{2}{*}{ Nitrogen } & Intact & $4.2 \pm 0.1^{\mathrm{e}}$ & $6.5 \pm 0.0^{\mathrm{d}}$ & $7.1 \pm 0.0^{\mathrm{c}}$ & $8.7 \pm 0.2^{b}$ & $10.4 \pm 0.1^{\text {a }}$ & 586.49 & $<0.001$ \\
\hline & Infested & $3.1 \pm 0.0^{\mathrm{d}}$ & $5.5 \pm 0.1^{\mathrm{c}}$ & $5.5 \pm 0.1^{\mathrm{c}}$ & $7.5 \pm 0.0^{b}$ & $9.3 \pm 0.0^{\mathrm{a}}$ & 2328.88 & $<0.001$ \\
\hline \multirow{2}{*}{ Phosphorus } & Intact & $0.2 \pm 0.0^{\mathrm{c}}$ & $0.8 \pm 0.0^{b}$ & $1.1 \pm 0.1^{\mathrm{a}}$ & $0.9 \pm 0.0^{b}$ & $0.8 \pm 0.0^{\mathrm{b}}$ & 122.84 & $<0.001$ \\
\hline & Infested & $0.3 \pm 0.0^{\mathrm{d}}$ & $0.8 \pm 0.0^{\mathrm{c}}$ & $1.1 \pm 0.0^{\mathrm{a}}$ & $0.9 \pm 0.0^{b}$ & $0.9 \pm 0.0^{b}$ & 426.95 & $<0.001$ \\
\hline \multirow{2}{*}{ Potassium } & Intact & $6.1 \pm 0.0^{b}$ & $6.7 \pm 0.0^{\mathrm{a}}$ & $6.2 \pm 0.0^{b}$ & $6.2 \pm 0.0^{\mathrm{b}}$ & $5.3 \pm 0.0^{\mathrm{c}}$ & 1081.75 & $<0.001$ \\
\hline & Infested & $6.2 \pm 0.0^{\mathrm{c}}$ & $7.5 \pm 0.0^{b}$ & $8.4 \pm 0.1^{\text {a }}$ & $7.3 \pm 0.1^{b}$ & $5.3 \pm 0.1^{\mathrm{d}}$ & 323.55 & $<0.001$ \\
\hline \multirow{2}{*}{ Sulphur } & Intact & $2.1 \pm 0.0^{b}$ & $1.9 \pm 0.0^{\mathrm{c}}$ & $2.4 \pm 0.0^{\mathrm{a}}$ & $1.4 \pm 0.0^{\mathrm{d}}$ & $1.2 \pm 0.0^{\mathrm{e}}$ & 667.07 & $<0.001$ \\
\hline & Infested & $3.3 \pm 0.1^{\mathrm{a}}$ & $2.7 \pm 0.0^{b}$ & $2.5 \pm 0.0^{b}$ & $1.6 \pm 0.0^{\mathrm{c}}$ & $1.6 \pm 0.0^{\mathrm{c}}$ & 189.78 & $<0.001$ \\
\hline \multirow{2}{*}{ Calcium } & Intact & $2.2 \pm 0.1^{b}$ & $1.9 \pm 0.0^{\mathrm{c}}$ & $2.6 \pm 0.0^{\mathrm{a}}$ & $2.0 \pm 0.0^{\mathrm{c}}$ & $1.1 \pm 0.1^{\mathrm{d}}$ & 292.30 & $<0.001$ \\
\hline & Infested & $3.7 \pm 0.0^{\mathrm{a}}$ & $3.7 \pm 0.0^{\mathrm{a}}$ & $2.8 \pm 0.0^{b}$ & $1.8 \pm 0.0^{\mathrm{c}}$ & $0.9 \pm 0.0^{\mathrm{d}}$ & 3275.15 & $<0.001$ \\
\hline \multirow{2}{*}{ Magnesium } & Intact & $0.9 \pm 0.0^{\mathrm{a}}$ & $0.6 \pm 0.0^{\mathrm{c}}$ & $0.7 \pm 0.0^{b}$ & $0.6 \pm 0.0^{\mathrm{c}}$ & $0.4 \pm 0.0^{\mathrm{d}}$ & 88.58 & $<0.001$ \\
\hline & Infested & $0.9 \pm 0.0^{\mathrm{a}}$ & $0.7 \pm 0.0^{b}$ & $0.6 \pm 0.0^{b}$ & $0.4 \pm 0.0^{\mathrm{c}}$ & $0.3 \pm 0.0^{c}$ & 123.41 & $<0.001$ \\
\hline \multirow{2}{*}{ Sodium } & Intact & $0.3 \pm 0.0^{a}$ & $0.3 \pm 0.0^{a}$ & $0.3 \pm 0.0^{a}$ & $0.3 \pm 0.0^{\mathrm{a}}$ & $0.2 \pm 0.0^{b}$ & 51.33 & $<0.001$ \\
\hline & Infested & $0.2 \pm 0.0^{\mathrm{c}}$ & $0.3 \pm 0.0^{b}$ & $0.3 \pm 0.0^{b}$ & $0.4 \pm 0.0^{\mathrm{a}}$ & $0.2 \pm 0.0^{\mathrm{c}}$ & 22.52 & $<0.001$ \\
\hline
\end{tabular}

Means in a row followed by the same letter do not differ significantly $(P=0.05)$ based on analysis of variance and Tukey's studentized range test; $F$ and $P$ values indicate the effects of fertilizer treatments on variation of respective nutrients; *data taken from Sarfraz et al. (2009). 
TABLE 6. Pair-wise comparison ( $t$-values) of nutrients in the leaves of Brassica napus grown in soils that received different fertilizer treatments and were either infested or not infested with Plutella xylostella larvae.

\begin{tabular}{lccccc}
\hline \multirow{2}{*}{ Leaf tissue nutrients (\%) } & \multicolumn{3}{c}{ Fertilizer treatment $\left(\mathrm{g} \mathrm{pot}^{-1}\right)$} \\
\cline { 2 - 6 } & 0.0 & 0.5 & 1.0 & 3.0 & 5.0 \\
\hline Nitrogen & $-9.82^{* * *}$ & $-17.59^{* * *}$ & $-18.16^{* * *}$ & $-7.06^{* * *}$ & $-12.66^{* * *}$ \\
Phosphorus & $3.19^{*}$ & $-0.81^{\mathrm{ns}}$ & $-0.62^{\mathrm{ns}}$ & $3.97^{* *}$ & $7.60^{* * *}$ \\
Potassium & $0.86^{\mathrm{ns}}$ & $33.20^{* * *}$ & $31.86^{* * *}$ & $13.07^{* * *}$ & $-0.64^{\mathrm{ns}}$ \\
Sulphur & $10.32^{* * *}$ & $39.19^{* * *}$ & $17.59^{* * *}$ & $7.79^{* * *}$ & $10.26^{* * *}$ \\
Calcium & $29.41^{* * *}$ & $72.59^{* * *}$ & $5.92^{* * *}$ & $-8.93^{* * *}$ & $-4.03^{* *}$ \\
Magnesium & $0.97^{\mathrm{ns}}$ & $1.96^{\mathrm{ns}}$ & $-1.97^{\mathrm{ns}}$ & $-6.16^{* * *}$ & $-3.02^{*}$ \\
Sodium & $-6.05^{* * *}$ & $-2.06^{\mathrm{ns}}$ & $-0.26^{\mathrm{ns}}$ & $2.68^{*}$ & $-1.36^{\mathrm{ns}}$ \\
\hline
\end{tabular}

ns $=$ non-significant at $P>0.05 ; *$ significant at $P \leq 0.05 ; * *=$ significant at $P \leq 0.01 ; * * *$ significant at $P \leq 0.001$.

\section{DISCUSSION}

The preference and performance of $P$. xylostella was significantly affected by the fertilizer treatments and the resulting nutrient contents of $B$. napus foliage. Female moths discriminated among host plants and selected those on which pre-imaginal development and survival were highest, and the longevity of the next generation of moths the longest. Plants subjected to herbivory by $P$. xylostella responded by producing elevated levels of some nutrients (e.g., sulphur), but levels of other nutrients declined in infested leaves (e.g., nitrogen). Regardless of the fertilizer treatment, plants responded to herbivory by increasing root mass (Figs 5 and 6). Evidently natural selection acting on the organisms in this system has favoured the development of physiological mechanisms that enable female moths to select those plants that confer the greatest potential fitness on their offspring and also compensatory responses in its host to counteract herbivory.

Ovipositing females discriminated between B. napus plants grown in fertilized and un-fertilized soil and these findings agree with previous reports. For instance, plants grown in fertilized soil were selected more frequently by ovipositing females of Pieris rapae (L.) (Lepidoptera: Pieridae) and Cassida canaliculata Laicharting (Coleoptera: Chrysomelidae) than those grown in un-fertilized soil (Myers, 1985; Chen et al., 2004; Heisswolf et al., 2005). Contrary to our findings, some reports indicate that females do not distinguish between plants grown in fertilized and un-fertilized soil. For example, ovipositing females of Lycaena tityrus Poda (Lepidoptera: Lycaenidae) did not discriminate between host plants growing in fertilized and un-fertilized soil; slightly more eggs were deposited on plants growing in un-fertilized than fertilized soil but the effect of host plant quality was not significant (Fischer \& Fiedler, 2000).

Several previous studies have examined the effects of insect herbivores on host plant nutrient levels, in particular nitrogen (e.g., Fischer \& Fiedler, 2000; Chau \& Heinz, 2006), but nitrogen content alone does not always explain the ovipositional preferences of females, particularly crucifer specialists such as $P$. xylostella that rely on additional stimuli. In $P$. xylostella, sulphur-deficient plants were less attractive for egg deposition than those growing in soils that received the maximum application of sulphur fertilizer (Gupta \& Thorsteinson, 1960; Marazzi et al., 2004). Oviposition was significantly higher on Brassica species growing in soil enriched with sulphur than those growing in soil deficient in sulphur (Gupta \& Thorsteinson 1960). Similarly, numbers of eggs laid on artificial leaves treated with the wax-free methanolic leaf-surface extracts of plants growing in soil with normal levels of sulphur (= field concentrations) were significantly higher (ca. 250\%) than on artificial leaves sprayed with sulphur-free plant extracts (Marazzi et al., 2004). The present data demonstrate that females preferred to oviposit on plants containing the highest concentrations of phosphorus, sulphur and calcium, and intermediate concentrations of nitrogen, potassium and magnesium (Figs 2 and 6).

In our research, larval and pupal survival was lowest (34.0 and $63.3 \%$, respectively) on plants growing in pots that received $5.0 \mathrm{~g}$ of fertilizer (ca. $10 \%$ total nitrogen dry weight basis), which does not accord with earlier reports of low nitrogen levels resulting in poor larval survival (Myers \& Post, 1981; Myers, 1985; Cates et al., 1987). Increased levels of nitrogen and other nutrients can lead to unbalanced amino acid profiles and high concentrations of organic acids in plant tissues (Williams \& Cronin, 2004); consequently such diets can be detrimental and even toxic to insects (Reese, 1979; Brodbeck et al., 1990). Similar to our results, significantly fewer L. tityrus developing on plants growing in soils that had been treated with a nitrogenous fertilizer survived than on plants growing in un-fertilized soil (Fischer \& Fiedler, 2000). Survival in response to treatment of the host plant with fertilizer could be species-specific. For instance, survival of two species of grasshoppers differed when reared on plants with low and high levels of nitrogen in their leaves. Survival of Phoetaliotes nebrascensis (Thomas) (Orthoptera: Acrididae) was greatest on plants containing low levels of nitrogen and decreased significantly in a linear fashion with increase in the level of nitrogen. In contrast, nitrogen levels in diets did not affect the survival of Melanoplus sanguinipes (Fabricius) (Orthoptera: Acrididae) (Joern \& Behmer, 1998).

Larval and pupal development was slower on plants growing in soils treated with fertilizer at rates of 0.0 and $5.0 \mathrm{~g} \mathrm{pot}^{-1}$ than on plants receiving $1.0 \mathrm{~g} \mathrm{pot}^{-1}$. Contrary to the present findings, higher nitrogen levels increased developmental rates in certain insects (Slansky \& Feeny, 1977; Cates et al., 1987; Hunter \& McNeil, 1997; Fischer $\&$ Fiedler, 2000). In the present study larvae consumed 


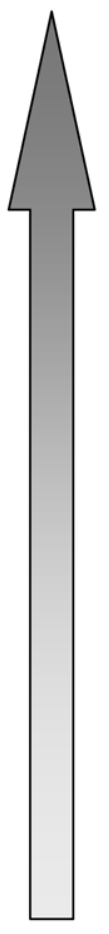

Brassica napus Host,
without Herbivory

\section{without Herbivory}

$\begin{array}{ll}\text { High } & \text { - large stem diameter } \\ \text { Fertilizer } & \text { - high leaf number } \\ \text { Treatment } & \text { - high leaf N content, but low or } \\ & \text { intermediate } \mathrm{P}, \mathrm{K}, \mathrm{S}, \mathrm{Ca}, \mathrm{Mg}, \\ & \text { and Na contents } \\ & \text { - intermediate root biomass }\end{array}$

$\begin{array}{ll}\text { Intermediate } & \text { - large stem diameter } \\ \text { Fertilizer } & \text { - intermediate leaf number } \\ \text { Treatment } & \text { - intermediate leaf N and Mg } \\ & \text { contents, high P, K, S, Ca, } \\ & \text { and Na contents } \\ & \text { - low or high root biomass }\end{array}$

Unfertilized
- small stem diameter
- low leaf number
- low leaf $\mathrm{N}$ and $\mathrm{P}$ contents, intermediate $\mathrm{S}$ and $\mathrm{Ca}$ contents, high $\mathrm{K}, \mathrm{Mg}$ and $\mathrm{Na}$ contents
- low root biomass

\section{Brassica napus Host, with Herbivory}
- large stem diameter
- high leaf number
- high leaf $\mathrm{N}$, intermediate $\mathrm{P}$,
low $\mathrm{K}, \mathrm{S}, \mathrm{Ca}, \mathrm{Mg}$, and $\mathrm{Na}$
contents
- intermediate root biomass

\section{Plutella xylostella - Host Plant Interaction}

- few eggs deposited

- low larval survival

- slow larval/pupal development

- low pupal weight

- small adult wing area

- short-lived adults

\section{- large stem diameter \\ - intermediate leaf number \\ - intermediate leaf N, S, Mg, and $\mathrm{Na}$ contents, high $\mathrm{P}, \mathrm{K}$, and $\mathrm{Ca}$ contents \\ - low or high root biomass}

- most eggs deposited

- highest larval survival

- fast larval/pupal development

- high pupal weight

- large adult wing area

- long-lived adults

Fig. 6. Overall effects of the different fertilizer treatments on Brassica napus plants without and with herbivory, and Plutella xylostella-host plant interactions.

more of the foliage of the plants grown in un-fertilized soils. Similarly, $P$. rapae larvae consumed more than twice the area of leaves of Brassica nigra (L.) plants growing in low fertility soils than of those growing in high fertility soils (48.2 and 21.0\%, respectively) (Meyer, 2000). Substantial evidence exists that insects compensate for low nitrogen concentrations by increasing food intake or feeding mainly on the most nitrogen-rich parts of plants (Slansky \& Feeny, 1977; White, 1984; Lavoie \& Oberhauser, 2004; Berner et al., 2005). In the present study, plants receiving intermediate fertilizer treatments yielded heavier pupae and a greater weight of silk. Similarly, the pupae of Coenonympha pamphilus L. (Lepidoptera: Satyridae) that developed on Festuca rubra L. (Poaceae) plants treated with fertilizer were heavier than those that developed on plants that were not treated with fertilizer (Mevi-Schütz et al., 2003). Pupal weight is often considered a good indicator of insect fecundity (Gilbert, 1984). In the present study, forewing areas were largest for insects fed on plants treated with fertilizer at a rate of $1.0 \mathrm{~g} \mathrm{pot}^{-1}$. In contrast to our results, host plant nutritional quality did not have a significant effect on wing length in $P$. rapae (Chen et al., 2004).

In the present study, females reared as larvae on plants grown in soils that received intermediate fertilizer treatments lived longer without food, suggesting that they had better food reserves. The adaptive advantage of selecting plants of maximal quality may be to confer greater fitness on their offspring in terms of increased longevity of the adults, increased wing area and increased egg production, when food is scarce. Adults of $P$. xylostella are highly migratory (Chapman et al., 2002; Sarfraz et al., 2005). Therefore, the above effects are likely to be advantageous in terms of migration and re-colonization, enabling them, for example, to travel in air currents without food over several days from northern Mexico to western Canada (Dosdall et al., 2004b) and then colonize canola fields in Canada.

Among the different nutrients assessed, the levels of nitrogen and sulphur in plants were most affected by herbivory: nitrogen levels declined but those of sulphur increased when plants were under attack by herbivores. It is likely that plants redirected some of their nitrogen budget to defense when infested, and this response may have deprived the herbivore of essential building blocks for protein synthesis. Sulphur is an important component of the defense system (glucosinolate-myrosinase) of Brassicaceae (Mithen, 1992; Sarfraz et al., 2006), and elevated concentrations of this substance in stressed and infested plants suggest that herbivory stimulated enhanced uptake of sulphur to better facilitate the defense response of $B$. napus. The greater root mass development in infested plants (Fig. 5) may enable them to more efficiently extract elements like sulphur from the soil, which are required for their defense. Other researchers have provided evidence that plants under biotic stress allocate more of their resources to defense than to growth (Rhoades, 1979; Herms \& Mattson, 1992). Similar to our findings, Inbar et al. (2001) reported that nutrientdeficient tomato plants contained elevated levels of defensive compounds such as phenolics.

Plants growing in soil that received 1.0 or $3.0 \mathrm{~g}$ fertilizer pot $^{-1}$ developed more robust root systems when infested with $P$. xylostella larvae than when not infested. This concurs with earlier findings in which turnip plants (Brassica rapa L.) infested with 20 larvae of $P$. xylostella 
had higher root dry weights than those infested with fewer larvae (Taylor \& Bardner, 1968). Plants can also increase their net aboveground productivity when infested (Belsky, 1986 and references therein) and various mechanisms have been identified that could contribute to such compensatory growth. They include intrinsic mechanisms such as photosynthetic enhancement and reallocation of available assimilates (Delting et al., 1979; Oesterheld \& McNaughton, 1988; Trumble et al., 1993) and extrinsic mechanisms such as nutrient recycling (Floate, 1981; Holland et al., 1992). Therefore, increased shoot growth could lead to increased root growth (McNaughton et al., 1998) and well nourished plants have a higher capability of compensating (and even overcompensating) than when nutrients are limiting. Although we did not continue this experiment to seed production, it is likely that plants grown in soils receiving the intermediate fertilizer treatment would produce better yields when infested as they have more robust root systems, which may facilitate a more rapid replacement of the tissues lost to herbivores. Meyer (2000) also noted that when growing in fertile soils plants were better able to maintain leaf growth rates when infested with caterpillars of $P$. rapae. Plants grown in un-fertilized soil were able to compensate through increased root and shoot growth and thus the present results support the compensatory continuum model of Maschinski \& Whitham (1989). According to this model, plants will more likely compensate for herbivore damage when growing in fertile soils, because the greater availability of nutrients enable plants to replace tissues lost to herbivores more efficiently. Although the observation that plants are better able to compensate for damage when growing in fertile soils is well supported by our results and those of other studies (Maschinski \& Whitham, 1989; Willis et al., 1995; Meyer, 2000; Dosdall et al., 2004a), there appear to be no studies on root development in $B$. napus grown in soils of different fertility and being eaten by $P$. xylostella.

Our findings support neither the plant stress nor plant vigour hypothesis. Un-fertilized plants of $B$. napus had low levels of nitrogen in their leaves and larvae of $P$. xylostella had to consume more foliage to compensate for this nutrient deficiency. Furthermore, plants growing in un-fertilized soils had fewer eggs laid on them and yielded lighter pupae than those that grew in soils that were subject to intermediate fertilizer treatments. Although the plants that grew in the soils subject to the highest fertilizer treatment had the thickest stems, greatest number of leaves and the highest leaf nitrogen contents, few eggs were laid on them and few larvae completed their development on these plants. It is likely that the plant stress and the plant vigour hypotheses apply to plants at the opposite ends of a continuum of responses between insects and their host plants. Although some insect species appear to respond more favourably to stressed host plants, and others to vigorous plants (Waring \& Cobb 1992), P. xylostella prefers plants growing in soils receiving intermediate fertilizer treatments. Our results indicate a complex set of interactions involving both bottom-up and top-down effects, which affect host plant morphology, oviposition site selection by female herbivores and fitness of their offspring.

ACKNOWLEDGEMENTS. This research was funded by the University of Alberta F.S. Chia Scholarship, the Queen Elizabeth II Scholarship, and the Alberta Society of Professional Biologists Scholarship to the senior author, and grants from the Alberta and Saskatchewan canola producer commissions and Canola Council of Canada to LMD. Thanks are due to D. Wynn, B. Laxton and G. Hilchie for valued assistance during this project. Special thanks are extended to K.D. Floate and three anonymous referees for critical review of the manuscript.

\section{REFERENCES}

AOAC International 2003a: Protein (crude) in animal feed: Combustion method, AOAC official method 990.03. In: Official Methods of Analysis of AOAC International, 17 th edition. Association of Official Analytical Chemists, Gaithersburg, MD, USA.

AOAC International 2003b: Metals and other elements in plants and pet foods: Inductively coupled plasma spectroscopic method, AOAC official method 985.01. In: Official Methods of Analysis of AOAC International, 17th edition. Association of Official Analytical Chemists, Gaithersburg, MD, USA.

BARKER A.M. \& MACZKA C.J.M. 1996: The relationships between host selection and subsequent larval performance in three free-living gramnivorous sawflies. Ecol. Entomol. 21: 317-327.

BELSKY A.J. 1986: Does herbivory benefit plants? A review of the evidence. Am. Nat. 127: 870-892.

Berner D., Blackenhorn W.U. \& Körner C. 2005: Grasshoppers cope with low host plant quality by compensatory feeding and food selection: $\mathrm{N}$ limitation challenged. Oikos 111: 525-533.

Brodbeck B.V., Mizzel R.F., French W.J., Anderson P.C. \& AldRICH J.H. 1990: Amino acids as determinants of host preference for the xylem feeding leafhopper, Homalodisca coagulata (Homoptera: Cicadellidae). Oecologia 83: 338-345.

Cates R.G., Henderson C.B. \& Redak R.A. 1987: Responses of the western spruce budworm to varying levels of nitrogen and terpenes. Oecologia 73: 312-316.

Chapman J.W., Reynolds D.R., Smith A.D., Riley J.R., Pedgley D.E. \& WorwoD I.P. 2002: High altitude migration of the diamondback moth Plutella xylostella to the U. K.: A study using radar, aerial netting, and ground trapping. Ecol. Entomol. 27: 641-650.

Chau A. \& Heinz K.M. 2006: Manipulating fertilization: a management tactic against Frankliniella occidentalis on potted chrysanthemum. Entomol. Exp. Appl. 120: 201-209.

Chen Y.Z., Lin L., Wang C.W., Yeh C.C. \& Hwang S.Y. 2004: Response of two Pieris (Lepidoptera: Pieridae) species to fertilization of a host plant. Zool. Stud. 43: 778-786.

Craig T.P. \& OHgushi T. 2002: Preference and performance are correlated in spittlebug Aphrophora pectoralis on four species of willow. Ecol. Entomol. 27: 529-540.

Craig T.P., Itami J.K. \& Price P.W. 1989: A strong relationship between oviposition preference and larval performance in a shoot-galling sawfly. Ecology 70: 1691-1699.

Delting J.K., Dyer M.I. \& Winn D.T. 1979: Net photosynthesis, root respiration, and regrowth of Bouteloua gracilis following simulated grazing. Oecologia 41: 127-134. 
Denno R.F., Larsson S. \& Olmstead K.L. 1990: Role of enemy-free space and plant quality in host-plant selection by willow beetles. Ecology 7: 124-137.

Dosdall L.M., Clayton G.W., Harker K.N., O'Donovan J.T. \& Stevenson F.C. 2004a: The effects of soil fertility and other agronomic factors on infestations of root maggots in canola. Agron. J. 96: 1306-1313.

Dosdall L.M., Mason P.G., Olfert O., Kaminski L. \& Keddie B.A. 2004b: The origins of infestations of diamondback moth, Plutella xylostella (L.), in canola in western Canada. In Endersby N.M. \& Ridland P.M. (eds): The Management of Diamondback Moth and Other Crucifer Pests. Proceedings of the Fourth International Workshop, 26-29 November 2001, Melbourne. Department of Natural Resources and Environment, Melbourne, pp. 95-100.

FisCher K. \& Fiedler K. 2000: Response of the copper butterfly Lycaena tityrus to increased leaf nitrogen in natural food plants: Evidence against the nitrogen limitation hypothesis. Oecologia 124: 235-241.

Flint H.M., Naranjo S.E., Leggett J.E. \& Henneberry T.J. 1996: Cotton water stress, arthropod dynamics, and management of Bemisia tabaci (Homoptera: Aleyrodidae). J. Econ. Entomol. 89: 1288-1300.

FlOATE M.J.S. 1981: Effects of grazing by large herbivores on nitrogen cycling in agricultural ecosystems. In Clark F.E. \& Rosswall T. (eds): Terrestrial Nitrogen Cycles. Royal Swedish Academy of Sciences, Stockholm, pp. 585-602.

Fox C.W. \& LaLonde R.G. 1993: Host confusion and the evolution of insect diet breadths. Oikos 67: 577-581.

GARTNER B.L. 1994: Root biomechanics and whole-plant allocation patterns: responses of tomato plants to stem flexure. $J$. Exp. Bot. 45: 1647-1654.

Gilbert N. 1984: Control of fecundity in Pieris rapae. I. The problem. J. Anim. Ecol. 53: 581-588.

Gupta P.D. \& Thorsteinson A.J. 1960: Food plant relationship of diamondback moth (Plutella maculipennis (Curt.)). II. Sensory regulation of oviposition of the adult female. Entomol. Exp. Appl. 3: 305-314.

Harcourt D.G. 1957: Biology of the diamondback moth, Plutella maculipennis (Curt.) (Lepidoptera: Plutellidae), in eastern Ontario. II. Life-history, behaviour, and host relationship. Can. Entomol. 12: 554-564.

HeInRIChs E.A. 1988: Plant Stress: Insect Interactions. Wiley \& Sons, New York, 492 pp.

Heisswolf A., Obermaier E. \& Poethke H.J. 2005: Selection of large host plants for oviposition by a monophagous leaf beetle: Nutritional quality or enemy-free space? Ecol. Entomol. 30: 299-306.

Herms A.A. \& Mattson W.J. 1992: The dilemma of plants: to grow or to defend. Q. Rev. Biol. 67: 283-335.

Holland E.A., Parton W.J., Delting J.K. \& Coppock D.L. 1992: Physiological responses of plant populations to herbivory and their consequences for ecosystem nutrient flow. Am. Nat. 140: 685-706.

HunTeR M.D. \& McNeil J.N. 1997: Host-plant quality influences diapause and voltinism in a polyphagous insect herbivore. Ecology 78: 977-986.

InBar M., Doostdar H. \& MAYer R.T. 2001: Suitability of stressed and vigorous plants to various insect herbivores. Oikos 94: 228-235.

Joern A. \& Behmer S.T. 1998: Impact of diet quality on demographic attributes in adult grasshoppers and the nitrogen limitation hypothesis. Ecol. Entomol. 23: 174-184.

Jones C.G. \& Coleman J.C. 1988: Plant stress and insect behavior: Cottonwood, ozone and the feeding and oviposition preference of a beetle. Oecologia 76: 51-56.
Koricheva J., Larsson S. \& Haukioja E. 1998: Insect performance on experimentally stressed woody plants: A metaanalysis. Annu. Rev. Entomol. 43: 195-216.

LARSSON S. 1989: Stressful times for the plant stress-insect performance hypothesis. Oikos 56: 277-283.

Lavoie B. \& Oberhauser K.S. 2004: Compensatory feeding in Danaus plexippus (Lepidoptera: Nymphalidae) in response to variation in host plant quality. Environ. Entomol. 33: 1062-1069.

LitTell R.C., Stroup W.W. \& Freund R.J. 2002: SAS ${ }^{\circledR}$ for Linear Models, 4th ed. SAS Institute Inc., Cary, NC, USA.

LoudA S.M. \& Collinge S.K. 1992: Plant resistance to insect herbivores: A field test of the environmental stress hypothesis. Ecology 73: 153-169.

Marazzi C., Patrian B. \& Städler E. 2004: Secondary metabolites of the leaf surface affected by sulphur fertilization and perceived by the diamondback moth. Chemoecology 14: 81-86.

Maschinski J. \& Whitham T.G. 1989: The continuum of plant responses to herbivory: The influence of plant association, nutrient availability, and timing. Am. Nat. 134: 1-19.

MatTson W.J. 1980: Herbivory in relation to plant nitrogen content. Annu. Rev. Ecol. Syst. 11: 119-161.

MatTson W.J. \& HaAcK R.A. 1987: The role of drought in outbreaks of plant-eating insects. Bioscience 37: 110-118.

McNaughton S.J., Banyikwa F.F. \& McNaughton M.M. 1998: Root biomass and productivity in a grazing ecosystem: The Serengeti. Ecology 79: 587-592.

Mevi-Schütz J., Goverde M. \& Erhardt A. 2003: Effects of fertilization and elevated $\mathrm{CO}_{2}$ on larval food and butterfly nectar amino acid preference in Coenonympha pamphilus L. Behav. Ecol. Sociobiol. 54: 36-43.

Meyer G.A. 2000: Interactive effects of soil fertility and herbivory on Brassica nigra. Oikos 88: 433-441.

Meyer G.A. \& Root R.B. 1996: Influence of feeding guild on insect response to host plant fertilization. Ecol. Entomol. 21: 270-278.

Mithen R. 1992: Leaf glucosinolate profiles and their relationship to pest and disease resistance in oilseed rape. Euphytica 63: 71-83.

MYERS J.H. 1985: Effect of physiological condition of the host plant on the ovipositional choice of the cabbage butterfly, Pieris rapae. J. Anim. Ecol. 54: 193-204.

Myers J.H. \& Post B.J. 1981: Plant nitrogen fluctuations of insect populations: A test with the cinnebar moth-tansy ragwort system. Oecologia 48: 151-156.

Oesterheld M. \& McNaughton S.J. 1988: Interspecific variation in the response of Themeda triandra to defoliation: The effect of time of recovery and growth rates on compensatory growth. Oecologia 77: 181-186.

Price P.W. 1991: The plant vigor hypothesis and herbivore attack. Oikos 62: 244-251.

Ramona W., Heidi A., Martin C. \& JaCK S. 2005: Fertility, root reserves and cost of inducible defenses in the perennial plant Solanum carolinense. J. Chem. Ecol. 31: 2263-2288.

REESE J.C. 1979: Interactions of allelochemicals with nutrients in herbivore food. In Rosenthal G.A. \& Janzen D.H. (eds): Herbivores: Their Interaction with Secondary Plant Metabolites. Academic Press, New York, pp. 309-320.

RHOADES D.F. 1979: Evolution of plant chemical defense against herbivores. In Rosenthal G.A. \& Janzen D.H. (eds): Herbivores: Their Interaction with Secondary Plant Metabolites. Academic Press, New York, pp. 3-54. 
Sarfraz M., Keddie A.B. \& Dosdall L.M. 2005: Biological control of the diamondback moth, Plutella xylostella (L.): A review. Biocontr. Sci. Technol. 15: 763-789.

Sarfraz M., Dosdall L.M. \& Keddie B.A. 2006: Diamondback moth-host plant interactions: Implications for pest management. Crop Prot. 25: 625-639.

Sarfraz M., Dosdall L.M. \& Keddie B.A. 2007: Resistance of some cultivated Brassicaceae to infestations by Plutella xylostella (Lepidoptera: Plutellidae). J. Econ. Entomol. 100 215-224.

Sarfraz M., Dosdall L.M. \& Keddie B.A. 2009: Host plant nutritional quality affects the performance of the parasitoid Diadegma insulare. Biol. Control 51: 34-41.

SAS Institute 2004: SAS User's Guide: Statistics. SAS Institute, Cary, NC, USA.

Scheirs J. \& BRUYN L.D. 2005: Plant-mediated effects of drought stress on host preference and performance of a grass miner. Oikos 108: 371-385.

Shelton A.M., Cooley R.J., Kroening M.K., Wilsey W.T. \& EIGENBRODE S.D. 1991: Comparative analysis of two rearing procedures for diamondback moth (Lepidoptera: Plutellidae). J. Entomol. Sci. 26: 17-26.

SKINNER H.R. 1996: Response of Bemisia argentifolii (Homoptera: Aleyrodidae) to water and nutrient stressed cotton. Environ. Entomol. 25: 401-406.

Slansky F. JR. \& FeEnY P. 1977: Stabilization of the rate of nitrogen accumulation by larvae of the cabbage butterfly on wild and cultivated food plants. Ecol. Monogr. 47: 209-228.

Steel R.G.D., Torrie J.H. \& Dickey D.A. 1997: Analysis of variance II: Multiway classifications. In Steel R.G.D., Torrie J.H. \& Dickey D.A. (eds): Principles and Procedures of Statistics: A Biometrical Approach. 3rd ed. WCB/McGraw-Hill, New York, NY, pp. 204-252.
Talekar N.S. \& Shelton A.M. 1993: Biology, ecology, and management of the diamondback moth. Annu. Rev. Entomol. 38: 275-301.

TAYLOR W.E. \& BARDNER R. 1968: Effects of feeding by larvae of Phaedon cochleariae (F.) and Plutella maculipennis (Curt.) on the yield of radish and turnip plants. Ann. Appl. Biol. 62: 249-254.

Tekeli A.S. \& Ates E. 2003: Yield and its components in field pea (Pisum arvense L.) lines. J. Centr. Eur. Agric. 4: 313-317.

THOMPSOn J.N. 1988a: Evolutionary ecology of the relationship between oviposition preference and performance of offspring in phytophagous insects. Entomol. Exp. Appl. 47: 3-14.

THOMPSON J.N. 1988b: Variation in interspecific interactions. Annu. Rev. Entomol. 19: 65-87.

Trumble J.T., Kolodny-Hirsch D.M. \& Ting I.P. 1993: Plant compensation for arthropod herbivory. Annu. Rev. Entomol. 119: 38-93.

WARING G.L. \& CoBB N.S. 1992: The impact of plant stress on herbivore population dynamics. In Bernays E. (ed.): InsectPlant Interactions. Vol. IV. CRC Press, Boca Raton, FL, pp. 167-187.

White T.C.R. 1969: An index to measure weather-induced stress of trees associated with outbreaks of psyllids in Australia. Ecology 50: 905-909.

White T.C.R. 1984: The abundance of invertebrate herbivores in relation to the availability of nitrogen in stressed food plants. Oecologia 63: 90-105.

Williams M.A. \& CRONIN J.T. 2004: Response of a gall-forming guild (Hymenoptera: Cynipidae) to stressed and vigorous prairie roses. Envir. Entomol. 33: 1052-1061.

Willis A.J., Ash J.E. \& Groves R.H. 1995: The effects of herbivory by a mite, Aculus hyperici, and nutrient deficiency on growth in Hypericum species. Aust. J. Bot. 43: 305-316.

Received June 3, 2009; revised and accepted August 13, 2009 